\title{
PSYCHE
}

\begin{tabular}{lll}
\hline VOL. XL JUNE, 1933 & No. 2
\end{tabular}

\section{UNUSUAL PREY OF BEMBIX}

\author{
By W. M. WHEELER AND RICHARD DoW \\ Harvard University, Cambridge, Mass.
}

It is usually supposed that the solitary wasps of the genus Bembix always provision their burrows with Diptera. Only one observation to the contrary has ever been reported in detail. ${ }^{1}$ One day while Dr. G. D. H. Carpenter was collecting Hesperiidæ on a muddy road in East Africa, he saw a Bembix hunting. First it seized a lycænid butterfly which it dropped, then it hovered over a skipper. Transferring its attention to another skipper, it pounced on its victim, and hung for a moment in the air. When Dr. Carpenter tried to catch it, the wasp flew off with its prey.

In addition to this observation, Mr. W. A. Lamborn ${ }^{2}$ has reported that several African species of Bembix take various Muscidæ and Orthoptera, and according to Professor Flaminio Ruíz, ${ }^{3}$ the wasps of the genus Bembix may feed their larvæ with "certain Lepidoptera of smooth texture." As the basis of the latter statement is unknown to the present authors, its accuracy must be questioned.

1Proc. Ent. Soc. London 1917: xli-xlii. 1918.

2Bull. Ent. Research 6: 63. 1915.

3Rev. Chilena Hist. Nat. 34: 156. 1930. 
During 1931, while the senior author was on the Harvard Zoological Expedition to Australia, he made a few observations on a Bembix colony which was storing its burrows with very unusual prey. At 3.30 p. m. on September 27, he was resting on the sandy shore of Lake Violet, a beautiful body of brackish water about 6 miles south of Wiluna, in the dry interior of Western Australia. As he was sitting in the shade of some bushes, he noticed almost at his feet a flourishing colony of an undetermined species of Bembix. The sand containing their burrows was so hot that the insects were able to open them only by practicing the interesting tactics described by $R$. N. Chapman for bembicine wasps in Minnesota. ${ }^{4}$ After locating the position of their nests, they would swoop down to the glowing surface of the sand, hastily scratch for a few seconds and then rise in the air to cool off. Frequent repetition of this behavior finally enabled them to penetrate the hot surface layer and enter their burrows. From time to time a Bembix would arrive with a slender object clasped to its thorax with the posterior legs, and projecting far beyond its abdomen. Closer inspection showed that the prey was a blue damsel fly which the junior author has identified as Austrolestes annulosus (Selys). After opening its burrow, the wasp very deftly slipped into it without releasing its prey. Three specimens of this insect, each netted with a wasp by Dr. P. J. Darlington, Jr., on October 2, proved to be males. Time did not permit an examination of the burrows, but there could be no doubt that all the wasps of the colony were storing only damsel flies as food for their larvæ. Indeed, these insects seemed to be the only available prey at the time. Diptera were extremely scarce on the shores of the lake, probably because they were being constantly devoured by the damsel and dragon flies, which were hawking about in great numbers. On the plants surrounding the lake in which they had passed their nymphal stages, the exuviæ were everywhere in evidence. It would seem, therefore, that in this locality the Bembix, being unable to secure their customary prey,

${ }^{4}$ Ecology 7: 425. 1926. 
had shifted their predatism to the very insects which were responsible for the dearth of Diptera.

Another Australian Bembix is also known to provide its young with unusual prey. Mr. A. E. Burns, a young hymenopterist of Melbourne, Victoria, informed the senior author that in Queensland he had taken a Bembix palmata F. Smith in the act of provisioning its burrow with a female nymph of a locustid.

Lest the reader conclude that all the Australian Bembix are aberrant in their choice of prey, it should be mentioned that among the insects caught by the Harvard Expedition is a Bembix furcata Erichson with a fairly large tabanid. These specimens were collected by Dr. P. J. Darlington, Jr., at Blackheath in the Blue Mountains, in January 1932. 

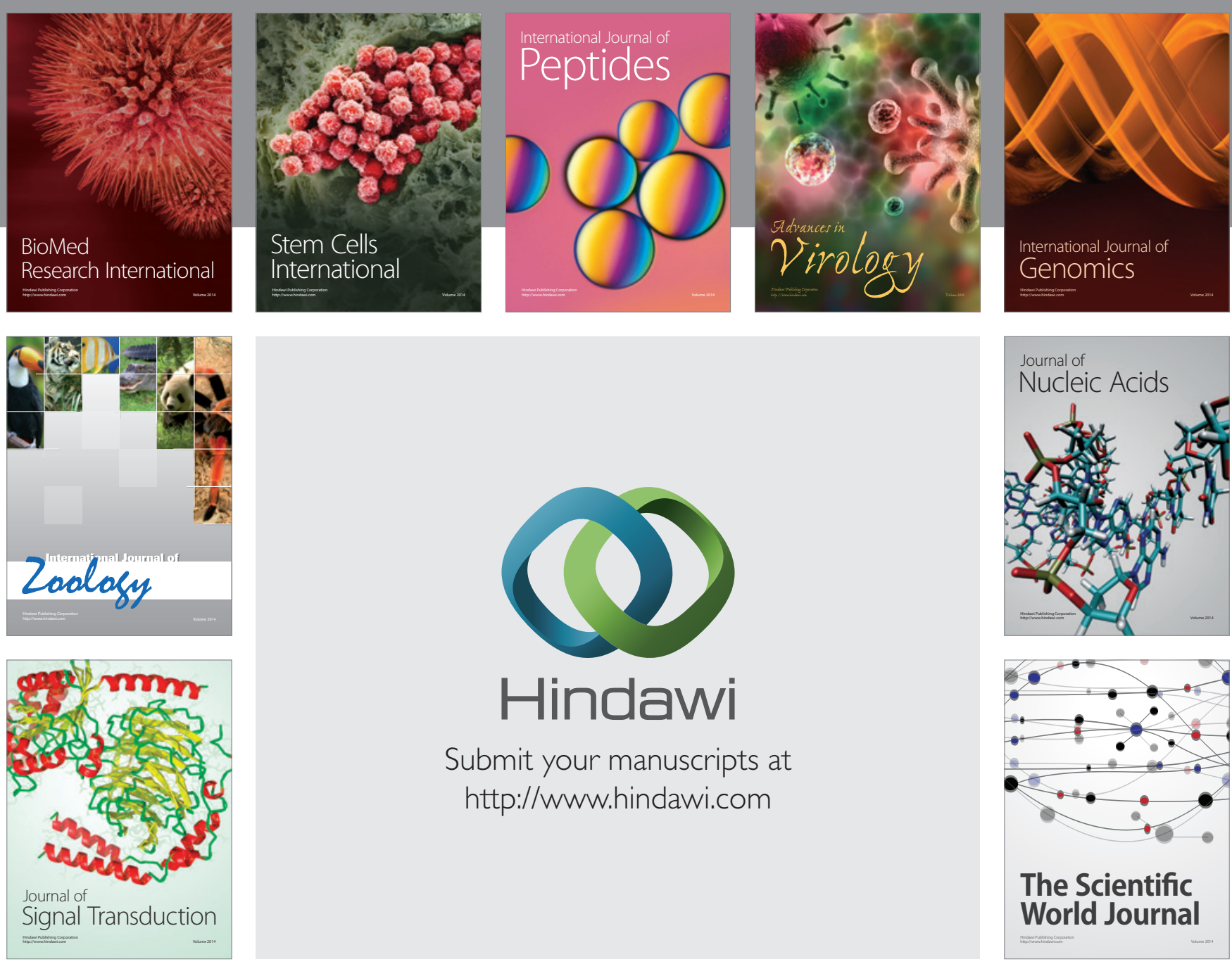

Submit your manuscripts at

http://www.hindawi.com
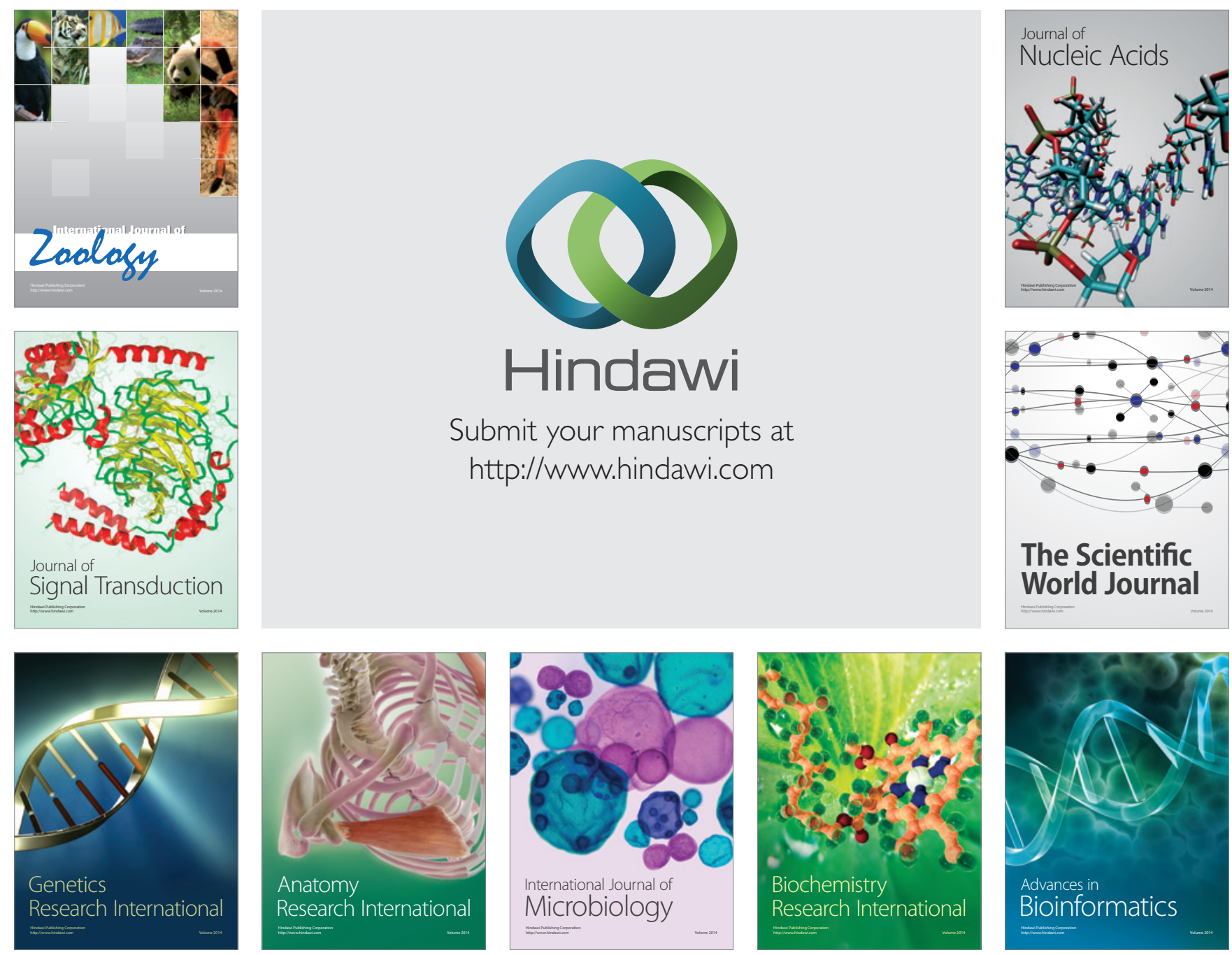

The Scientific World Journal
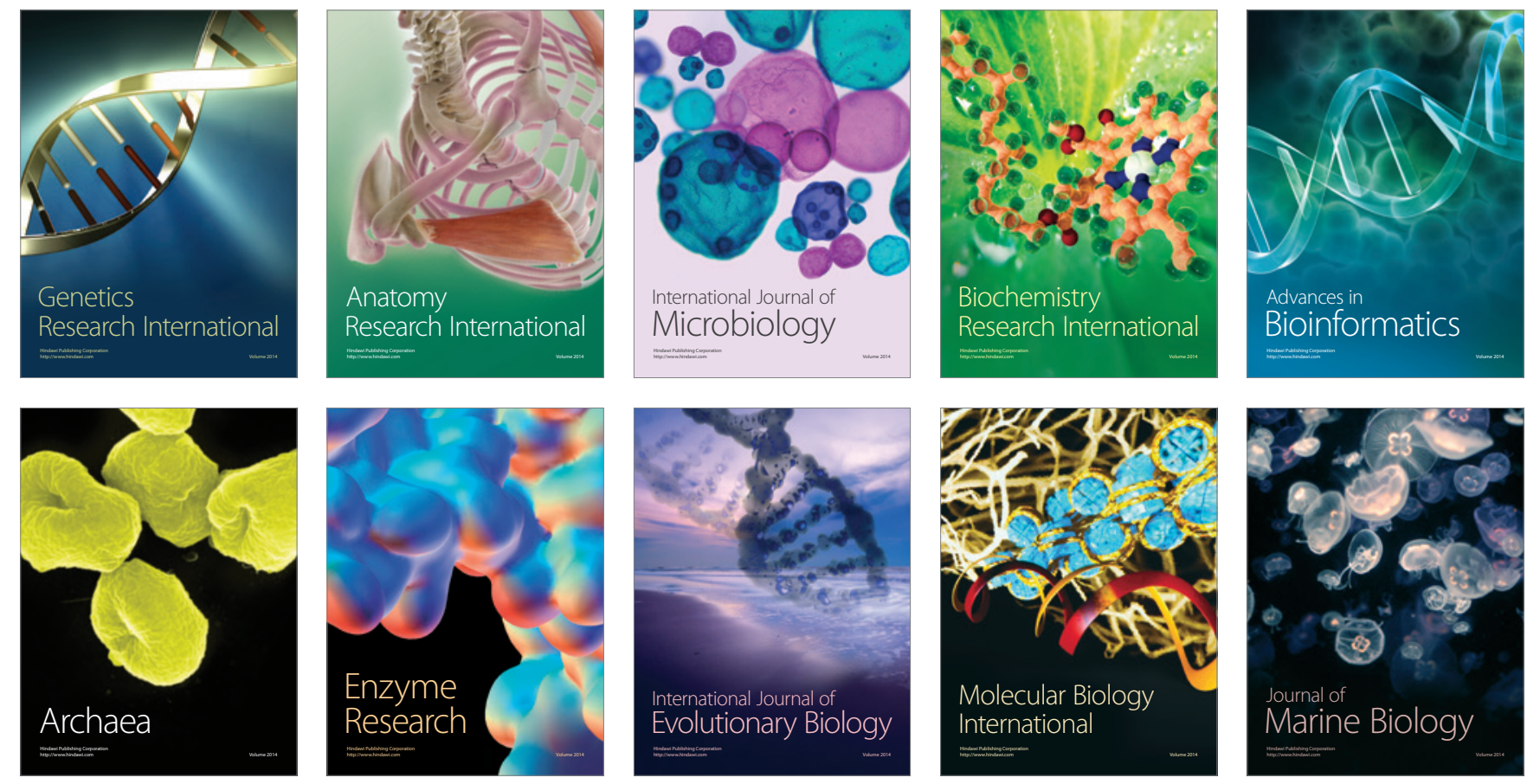